University of the Pacific

Scholarly Commons

College of the Pacific Faculty Articles

All Faculty Scholarship

Spring 4-1-2012

\title{
Between Catastrophe and Carnival: Creolized Identities, Cityspace, and Life Narratives
}

Cynthia Dobbs

University of the Pacific, cdobbs@pacific.edu

Daphne Lamothe

Smith College

Theresa Tensuan

Haverford College

Follow this and additional works at: https://scholarlycommons.pacific.edu/cop-facarticles

Part of the English Language and Literature Commons, Feminist, Gender, and Sexuality Studies Commons, and the History Commons

\section{Recommended Citation}

Dobbs, C., Lamothe, D., \& Tensuan, T. (2012). Between Catastrophe and Carnival: Creolized Identities, Cityspace, and Life Narratives. Biography, 35(2), v-xi. DOI: 10.1353/bio.2012.0021

https://scholarlycommons.pacific.edu/cop-facarticles/275 


\title{
BETWEEN CATASTROPHE AND CARNIVAL: CREOLIZED IDENTITIES, CITYSPACE, AND LIFE NARRATIVES
}

\author{
CYNTHIA DOBBS, DAPHNE LAMOTHE, AND THERESA TENSUAN
}

What are the intersections between increasingly globalized urban spaces, histories of violent diaspora, and the formation of creolized identities through language? How do theories of creolization, diaspora, and postmodern spatiality help us understand the power of life narratives in relation to city spaces? How are cities experienced and imagined as sites of creolization and cosmopolitanism, especially by those located at the margins of centers of power? In conversation with the influential work of spatial theorists Edward Soja and others, bell hooks notes, "'the politics of location' necessarily calls those of us who would participate in the formation of counter-hegemonic cultural practice to identify the spaces where we begin the process of re-vision" (145). ${ }^{1}$ The essays that follow engage precisely the sorts of resistant cultural practices hooks imagines, introducing us to authors who powerfully articulate the intersectionality of identities seeking spaces of belonging within the city.

Running through this cluster of essays is an understanding of creolization of identities, languages, and spaces as a dynamic and historically situated process of hybridization in which ethnic and cultural identities are continually reexamined, resituated, and rearticulated. The life narratives examined here illuminate the functioning of urban spaces in the construction of creolized subjects whose identities are organized in manners that can challenge master narratives. Usefully summarizing the relationship between space and creolized identities in the theories of Frederic Jameson and Edward Soja, Elizabeth Abel writes, "Redefining space as the dynamic medium through which history occurs, rather than the static backdrop to historic action, they [Lefebvre, Soja, and Jameson] contended that space . . . becomes a charged and dynamic medium, a sphere of contestation and negotiation through which multiple histories are enacted and identities produced" (17). As this cluster 
of essays demonstrates, the life narratives of migratory peoples make visible (and audible) radicalizing processes of creolization and the tensions between vernacular, local identities and urban, cosmopolitan identities in ways not as readily visible to those who inhabit centers of power, and whose freedom to move across boundaries remains unfettered and often unconscious.

The essays in this cluster implicitly and explicitly use Édouard Glissant's conceptualization of creolization as a dynamic and historically situated process, through which to frame, contextualize, and analyze identity, subjectivity, and community. They introduce a wide range of genres that all can be grouped under the general category of "life narrative": autobiography, biography, travelogue, translations, sculpture, and music. Each essay focuses on the artists' lives and the lives commemorated in their literature and art, seeking insight into the processes and effects of transnational migration, structures of inequality, and emergent subjectivity. Following Sidonie Smith and Julia Watson's illuminating insights into the ways in which creators of life narratives work from their "historically and culturally specific understandings of memory, experience, identity and embodiment, and agency" to "both reproduce the various ways in which they have been culturally read and critique the limits of those cultural modes of self-narrating" (183), we as co-editors bring together these diverse essays in an effort to draw out the common concerns and patterns embedded in each analysis of the representation of lives in the creole city. We offer this collection in the critical and creative spirit that Françoise Lionnet has defined as "métissage," the energy that circulates "under the articulated, written, organized surface of the narrative . . that can alternatively disrupt the surface layer . . or pull together and unify seemingly contradictory or discontinuous narrative modes" (331).

In “'Dust to Cleanse Themselves,' A Survivor's Ethos: Diasporic Disidentifications in Zeitoun," Valorie Thomas focuses on Dave Eggers's narrative of the experiences of a Muslim family in the wake of Hurricane Katrina to explore what Thomas defines as "identities structured by contingency" (271). Drawing from Jose Muñoz's analysis of disidentification as a practice that "exposes the dissonance beneath the enforced harmonies of the master narrative, dislodging hidden meanings embedded in publicly circulated versions of official truth" (272), Thomas shows how the interrelations between the experiences of a Syrian immigrant caught in a military-industrial dragnet as he works to aid survivors of this unnatural disaster, and the practices of his New Orleans-bred wife as she searches for her missing husband, invoke "an ethos of survival [that is] processual, experiential, and episodic ... in which belonging is a matter of creating context through cultural memory [and] improvisation" (274). Working against the trajectory of conventional Christian 
conversion narratives in which cataclysm is a catalyst for individual transformation and grace, Thomas's reading of Zeitoun reveals how the narrative foregrounds the play of spiritualities, the workings of resistance, and the breakdown of institutions of domination; the text thus opens up new spaces of consciousness, in and through which identity becomes a "function of communal consciousness" (280).

Both Thomas and Dawn Fulton frame their analyses through the perspectives of the immigrant subject, perhaps because the narratives of marginalized peoples reveal what it is to live through, enact, and embody the violent and volatile remaking of societies and human subjects through processes of creolization. Where Thomas examines the disidentifications engendered by the Muslim and New Orleanian diasporas post-Hurricane Katrina, Fulton shifts our attention to representations of the Maghrebian diaspora relegated to the outskirts of twentieth and twenty-first centuries Paris. Mohand Mounsi's creolized Paris is scarred by the immigrant's dual alienation from both the French republic and Algerian homeland. Fulton's analysis maps Parisian inhabitants' relationships to power through an exploration of Mounsi's use of the trope of the "urban silhouette" to make visible the unseen and unacknowledged Algerian immigrant presence in the city. Fulton's analysis underscores the "frictions" postcolonial immigration creates in a capital city that is imagined to embody both Enlightenment ideals of Republicanism and contemporary urban ideals of cultural mixing.

In her "Militant Cosmopolitan in a Creole City: The Paradoxes of Jacques Roumain," Kathy Richman continues Fulton's analysis of what we might call the postcolonial visibility project, extending it from the creole city (in this case, Port-au-Prince) to the countryside of Haiti. Richman traces the genealogy of Roumain's 1944 novel Gouverneurs de la Rosée and the international translations and re-visions the novel engendered: Langston Hughes and Mercer Cook's 1947 English translation, Masters of the Dew; the 1964 Cuban film, Cumbite; and the 1980 Haitian serialized graphic narrative, Mèt Larouzé. In so doing, Richman tells not only the life story of a Haitian writer negotiating diverse ethnic, linguistic, and class identities and affinities, but also the life story of his creole novel-its figurative sons and daughters emerging in diverse literary, cinematic, and graphic forms that speak to the historical contexts of Haiti at critical junctures. Richman tracks the tensions between and among Jacques Roumain's own relatively privileged life as a cosmopolitan member of the social elite of Port-au-Prince, his growing allegiance to the Communist party, and his interest in capturing the vernacular lives of the alienated rural poor of the Haitian countryside. Richman reveals how these biographical tensions are made manifest in Gouverneurs de la Rosée's fictional 
tale of Manuel, a Haitian peasant who returns from Cuba with "new ideas and language (including the Spanish word 'buelga' or 'strike')," which "inspire him to reinvigorate an important Haitian tradition of cooperative farming, the coumbite" (306). As Richman argues, Roumain's novel, written in standard French, Haitian Creole, and creolized French, highlights the ways in which telling creolized, migratory life stories invariably calls for aesthetic, political, and linguistic acts of mediation and multidirectional translations. In the various translations and re-interpretations of Gouverneurs de la Rosée, we see that the disempowered's struggle for articulation and visibility is a story that, for better and worse, persists.

Art historian Susanna Gold's essay on the African American sculptor Edmonia Lewis and her contribution of a statue of Cleopatra to the 1876 Centennial Exhibition in Philadelphia provides another view of the conflict between nationalist constructs and creolized subjectivities. Her analysis illuminates the deep irony inherent in the life story of Edmonia Lewis, whose background merged Native American, African, and European ancestries, yet who was compelled to leave the "New World" site of origin for creolized societies, in favor of Old World Europe, whose cosmopolitanism made it more open to African American artistic expression. In returning to the United States to exhibit a sculpture of Cleopatra that embodies empire in a state of agony and impending demise, Lewis offered a vision of the potentials and pitfalls of empire-building to a nation intent on reinventing and reunifying itself in the decade following the Civil War. Gold's analysis of the symbolism embedded in Lewis's creative decisions as a sculptor invites us to consider if, at a critical historical juncture, a nation's founding city (in this case Philadelphia) might have become a site of a renewed, reinvigorated, and more inclusive creole society.

Kristin A. Lindgren's "Contact Zones and Border Crossing: Writing Deaf Lives" extends our notions of what constitutes the creolized subject to a genre too commonly overlooked: the hybridized life writings of Deaf authors that merge conventions of written and sign languages. Lindgren introduces us to Pierre Desloges's 1779 foundational essay validating sign language as a means of articulating the then-questioned humanity of Deaf people. Noting the analogous strategies and editorial conventions framing eighteenth and nineteenth century slave narratives, Lindgren reveals Desloges's defense of sign language as a "threshold genre" that allows for an articulation of the doubled consciousness of individuals with citizenship in two often incommensurate societies: French and subaltern Deaf communities. Lindgren employs the concept of Deaf literature as threshold genre in her analysis of the contemporary life writing of Emmanuelle Laborit, whose 1994 autobiography 
Le Cri de la Mouette, later translated into English as The Cry of the Gull, explicitly attempts to infuse written language with what Lindgren characterizes as the "performative vitality" of sign language (348). A nationally renowned actress and director of the International Visual Theatre, Laborit transforms the conventions of autobiography to enact and announce Deaf life writing as an act of doubled or even tripled translation: from an oral linguistic register to a performative, bodily register-and back again.

Lindgren's essay introduces us to writers situated in Paris, but does not focus on the specificity of place in its analysis. In contrast to the preceding essays that theorize the importance of particular locations, both metropolitan and provincial, Lindgren emphasizes, theorizes, and imagines a third spacea textual site. The inclusion of this essay in the cluster invites us to consider the translatability of the concept of creolization to a historical and geographical example that is on its surface divorced from the experiences of enslavement and colonialism that constitute the historical and structural foundations for the formation of creolized societies. Lindgren's association of the emergence of a tradition of Deaf literature with slave narratives, and her identification of Deaf subjects with subalternity invite the possibility that these formulations carry over to other experiences, contexts, and locations. Just as the translation of the sign language text to the written word carries with it gains and losses in communication, so does the translation of the concept of creolization when transported to other cultural and social contexts.

Daphne Lamothe considers the limits and possibilities inherent in acts of cultural translation in the essay "Carnival in the Creole City," in which she assesses the social and political choreographies that shape and frame the participation of individuals and of communities in metropolitan centers ranging from Barranquilla, Colombia to Brooklyn, New York to Jacmel, Haiti. Aligning the performances and processions of carnival with visions of city street life, Lamothe articulates the differences between the smooth circulation of commodified representations of creole culture in American popular music and the bump and grind experienced by creole subjects in American cities and on Caribbean islands. From the lyrical play of Wyclef Jean in his Carnival albums to the self-reflexive meditation of Edwidge Danticat on the meanings of Jacmel's Carnival ritual in her Haitian travel narrative, After the Dance, Lamothe reveals how carnival traditions "allow celebrants to imagine different social and political realities, if only temporarily" (363). Those texts that are most historically and geographically situated depict creolized peoples who contend with national, ideological, and historical forces while also defying easy categorization and thus facile commodification: a fisherman who creates art out of found objects, a farmer who animates a complex cultural register akin to that 
of Gwendolyn Brooks's Satin-Legs Smith. Such figures create a backbeat to what Lamothe characterizes as Danticat's own (wishful) imagining of carnival as a virtual "baptism by crowd," "with the potential to wash away the emigrant's 'sins' of abandonment of family, forgetting of history, and alienation from her country and culture of origins" $(365,369)$. Danticat's description of what carnival offers captures something of the longing and tension evident in all these narratives about life in the creolized city: the inherently contingent, slippery, performative nature of carnival as cultural signifier of creolization reveals both the seduction of such a vision of belonging and the dangers of the denial of difference.

Just as Lamothe's essay illuminates the "paradoxical" in the idea and experience of Carnival, so do we acknowledge and invite the fruitful tensions inherent in our construction of the concept of life stories from "the creole city." Recognizing that creolization is a process rooted in the Caribbean histories of plantation slavery and colonialism, we intend for it to invoke more than easily commodified and assimilated hybridity, heterogeneity, or multiculturalism. In that sense the creole is in tension with the connotations carried by the concept of the cosmopolitan city, particularly in this era of globalization, of cosmopolitan wealth and "worldliness," and the invitation of only certain kinds of difference. The creole city is not the cosmopolitan or globalized city, although it certainly is related to these formulations, in that "creolization" insistently recalls histories of violence, dislocation, and displacement, as well as processes of remaking and transformation. When taken in their totality, what these essays recall is that cosmopolitan, "first world" cities and citizens construct their identities in a dialectic with their "third world" inhabitants. They remind us also of the fact that historically marginalized individuals are always constructing new and powerful subjectivities, cultures, and communities out of these very same processes of forced (and voluntary) proximities within the city. Cities profoundly shape the lives and life narratives emerging within their contested boundaries-and as these essays reveal, cities have lives and life stories of their own. The following essays suggest that stories of cities constitute forms of life writing that illuminate the formation of individual and collective identities in response to processes of globalization, the workings of empire, and manifestations of racial and cultural inequity and pluralism.

\section{NOTE}

1. For discussions of the politics of space and location, see especially Soja, Lefebvre, and Keith and Pile. 


\section{WORKS CITED}

Abel, Elizabeth. Signs of the Times: The Visual Politics of Jim Crow. Berkeley: U of California P, 2010. Print.

Glissant, Édouard. Caribbean Discourse: Selected Essays. Charlottesville: U of Virginia P, 1999. Print.

hooks, bell. Yearning: Race, Gender, and Cultural Politics. London: Turnaround, 1991. Print.

Keith, Michael, and Steve Pile, eds. Place and the Politics of Identity. London: Routledge, 1993. Print.

Lefebvre, Henri. Writings on Cities. London: Blackwell, 1996. Print.

Lionnet, Françoise. Autobiographical Voices: Race, Gender, Self-Portraiture. Ithaca: Cornell UP, 1991. Print.

Smith, Sidonie, and Julia Watson. Reading Autobiography: A Guide for Interpreting Life Narratives. 2nd ed. Minneapolis: $U$ of Minnesota P, 2010. Print.

Soja, Edward. Postmetropolis: Critical Studies of Cities and Regions. Oxford: Blackwell, 2000. Print. 